УДК 597.556.331.1(282.247.112)

doi: $10.31140 /$ j.vestnikib.2019.4(211).3

\title{
ЗИМНЕЕ РАСПРЕДЕЛЕНИЕ ОКУНЯ В ГОРНОЙ ОЗЕРНО-РЕЧНОЙ СИСТЕМЕ
}

\author{
В.И. Пономарев \\ Институт биологии Коми научного центра Уральского отделения Российской академии наук, Сыктывкар \\ E-mail: ponomarev@ib.komisc.ru
}

\begin{abstract}
Аннотация. Дана общая характеристика распределения и состояния группировок окуня на зимних местообитаниях в горных и предгорных озерах бассейна р. Малый Паток (Приполярный Урал) в районе выхода реки из горной полосы на равнину. Вид отмечен в восьми из 19 озер, они населены окунем в период открытой воды. Выявлены различия размерно-возрастных показателей окуня из различных водоемов озерно-речной системы, черты сходства и различия в характере зимнего питания окуня. Результаты сравнительного изучения ряда биологических показателей свидетельствуют о стабильности и долговременном улучшении состояния популяции окуня.
\end{abstract}

Ключевые слова: окунь, Приполярный Урал, горные и предгорные озера, пространственное распределение, биологические показатели

\section{Введение}

В ходе предпринятых в 1996-2014 гг. ихтиофаунистических исследований водоемов бассейна р. Малый Паток было зарегистрировано 11 видов рыб (Бассейн ..., 2007). При этом только в русле водотока встречаются все выявленные здесь виды рыб из девяти семейств - лососевые, сиговые, хариусовые, щуковые, карповые, балиторовые, налимовые, окуневые и рогатковые. В озерах отмечено восемь видов рыб; установлено, что 21 из 28 обследованных озер бассейна Малого Патока населено рыбой, причем во всех из них встречена щука, в 19 озерах обнаружены окунь и сибирский сиг-пыжьян, в 12 - ерш, в восьми плотва, в шести - обыкновенный гольян, в трех европейский хариус, в двух - обыкновенный подкаменщик. Атлантический лосось, усатый голец и налим отмечены только в русле р. Малый Паток и ее притоках.

Результаты многолетнего изучения динамики структуры рыбного населения позволили сделать заключение о функциональной дифференциации озер, входящих в озерно-речную систему, обра-

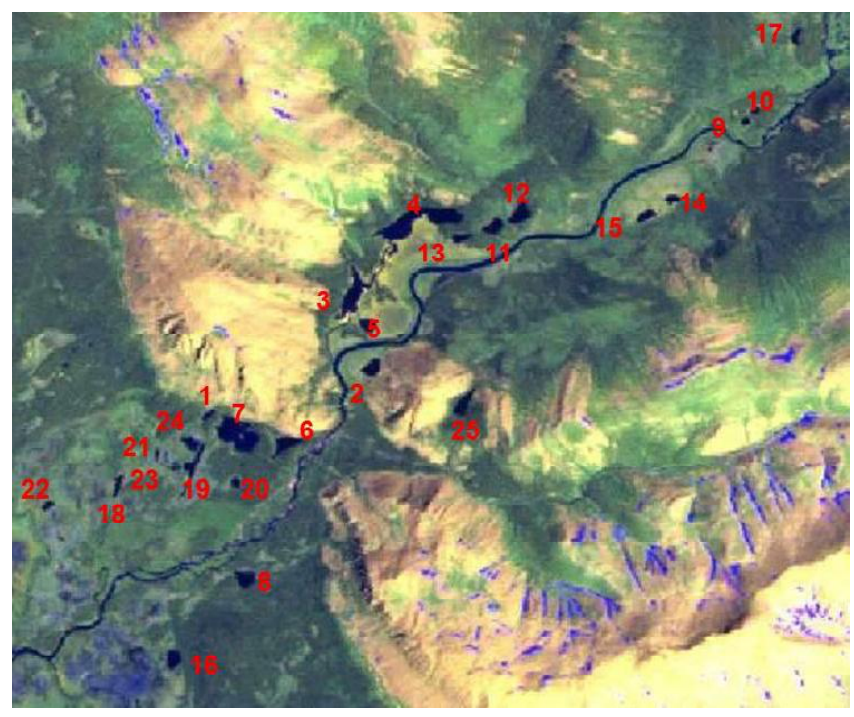

Рис. 1. Схема района исследований в бассейне р. Малый Паток. зованную в районе выхода р. Малый Паток из горной области на равнину, при прохождении рыбами ключевых этапов жизненного цикла (Пономарев, 2019). В период открытой воды мы неоднократно наблюдали массовые перемещения сига, щуки и окуня из одного водоема рассматриваемой системы в другие, причем в ряде случаев вне связи со временем нереста. В частности, щука регулярно мигрировала из глубоководных озер в освободившиеся ото льда мелководные нагульные водоемы вслед за молодью сига.

Хорологическая структура рыбного населения водоемов уральского Припечорья и всего крайнего европейского Северо-Востока остается одним из наименее изученных аспектов их экологии, в особенности это касается подледного периода (Пономарев, 1998). Между тем, зимовка рыб, сопровождающаяся общим снижением их двигательной и пищевой активности, рассматривается как один из ключевых этапов их онтогенеза (Никольский, 1974). Данная работа представляет собой первую попытку получения характеристики подледного распределения окуня - одного из наиболее массовых видов рыб озер бассейна р. Печоры.

\section{Материалы и методы}

Поскольку все озера, входящие в озерно-речную систему бассейна $\mathrm{p}$. Малый Паток в районе выхода этого водотока из горной области и обследованные на предмет характеристики структуры рыбного населения и динамики его изменений, не имеют географических названий, для удобства они были обозначены автором условными номерами (рис. 1). Детальное описание этих водоемов содержится в предыдущих публикациях (Пономарев, 2019).

С 2000 г. мы регулярно проводили ихтиологические исследования в бассейне р. Малый Паток в подледный период. Результаты этих исследований позволяют охарактеризовать распределение и состояние группировок окуня на зимних местообитаниях. 
Сбор и обработку ихтиологического материала осуществляли на свежепойманной рыбе в соответствии с общепринятыми методами исследований (Правдин, 1966; Мина, 1976). Отлов рыб выполняли с помощью крючковых снастей: зимних удочек с мормышкой и блесной, а также поплавочных удочек. Регистрировали дату, время, величину и состав уловов, а также следующие показатели отловленных рыб: промысловую длину, общую массу тела, пол и стадию зрелости. В марте-апреле 2008 г. отбирали образцы желудочно-кишечного тракта окуня для выяснения характера его питания подо льдом. Определение возраста окуня выполнено по чешуе, идентификация содержимого пищеварительного тракта рыб по счетно-весовому методу (Методическое..., 1974).

Полевые сборы были сделаны в подледный период на 12 водоемах. В крючковых уловах из озер 2, 4-7, 11, 12 и 13 присутствовал окунь. Кроме того, в озерах 6, 7 и 11 зарегистрирована щука, озерах 4 и 7 - сиг и плотва. Сразу отметим, что контрольные выборки в озерах 8-10 и 19 отобрать не удалось. В случае с озерами 8 и 19 отсутствие уловов объясняется их мелководностью и промерзанием в зимний период до дна. В отличие от этих мелководных предгорных водоемов, озера 9 и 10 имеют все условия для обитания рыб на протяжении всего года - располагаются в горной части долины реки и соединяются протоками как между собой, так и через озеро 9 с руслом Малого Патока.

\section{Результаты и обсуждение}

Проточное озеро 2 площадью 3.3 га расположено на высоте 229 м над ур.м. в заболоченной долине реки, обладает округлой формой и простой береговой линией с пологими задернованными заболоченными берегами. Связано с руслом р. Малый Паток самостоятельной протокой. Этот водоем характеризуется отсутствием четко выраженной литорали, илистыми грунтами с валунами и распространенными глубинами от 0.8 (на литорали) до 10 м (батиаль) при максимальной глубине $15 \mathrm{~m}$.
Из табл. 1, в которой представлены результаты анализа контрольных уловов окуня из озера 2 , видно, что с годами практически все используемые биологические показатели последовательно растут, что свидетельствует о благополучии местной группировки окуня.

Озеро 4 расположено на высоте 230.1 м над ур.м., его площадь 23 га. Это обладающее сложной формой озеро соединяется протокой с другим ледниковым озером бассейна р. Малый Паток, которое уже напрямую связано собственной протокой с руслом водотока. Водоем характеризуется наличием илистых, песчаных и каменистых грунтов.

Как следует из табл. 2, за шесть лет исследований все без исключения биологические показатели группировки окуня озера 4 на зимних местообитаниях в целом проявили выраженную стабильность, а размерно-весовые и возрастные несколько увеличились. Это свидетельствует о позитивной тенденции увеличения размерно-весовых показателей за период времени протяженностью почти 14 лет.

Некоторое ухудшение показателей, полученных в 2003 г., по сравнению с 2000 г. можно объяснить влиянием на динамику размерно-весовых показателей появившихся в уловах 2003 г. представителей весьма многочисленного поколения нереста 2000 г. Сопоставление этих данных с материалами, полученными в 2012 г. и особенно в 2014 г., однозначно говорит о качественно положительных изменениях наблюдаемых показателей.

Озеро 5 расположено на высоте 229.5 м над ур.м., его площадь 2.7 га. Этот водоем связан с p. Малый Паток собственной протокой, сливающейся с протокой еще одного озера и впадающей в русло основного водотока. Обладает округлой формой и простым характером береговой линии, литораль отсутствует. Берега пологие, задернованные и заболоченные. Средняя глубина 2 м, максимальная - 10 м. Дно илистое, с крупными валунами.

Исследования на озере 5 в подледный период проводили лишь два раза, но и здесь проявилось

Биологическая характеристика уловов окуня в озере 2

Таблица 1

\begin{tabular}{|c|c|c|c|c|c|c|}
\hline $\begin{array}{c}\text { Число } \\
\text { возрастных } \\
\text { групп } \\
\end{array}$ & $\mathrm{n}$ & $\begin{array}{l}\text { Средняя длина, мм } \\
\text { минимум-максимум }\end{array}$ & $\begin{array}{c}\text { Средняя масса, г } \\
\text { минимум-максимум }\end{array}$ & $\begin{array}{c}\text { Доля } \\
\text { половозрелых, } \\
\text { \% } \\
\end{array}$ & $\begin{array}{c}\text { Средний } \\
\text { возраст, лет }\end{array}$ & $\begin{array}{c}\text { Соотношение } \\
\text { самцы:самки, } \\
\% \\
\end{array}$ \\
\hline \multicolumn{7}{|c|}{ Апрель 2008 г. } \\
\hline 6 & 26 & $\frac{153.5 \pm 4.5}{122-208}$ & $\frac{64.2 \pm 7.71}{30-166}$ & 61.5 & 6.3 & $38.5: 61.5$ \\
\hline \multicolumn{7}{|c|}{ Февраль 2011 г. } \\
\hline 6 & 27 & $\frac{166 \pm 3.3}{120-202}$ & $\frac{77 \pm 4.72}{49-140}$ & 85.2 & 6.8 & 40.7:59.3 \\
\hline \multicolumn{7}{|c|}{ Март 2014 г. } \\
\hline 6 & 21 & $\frac{188.2 \pm 3.98}{164-232}$ & $\frac{107.2 \pm 8.36}{61-213}$ & 100 & 11.7 & 71.4:28.6 \\
\hline
\end{tabular}


Биологическая характеристика уловов окуня в озере 4 бассейна р. Малый Паток

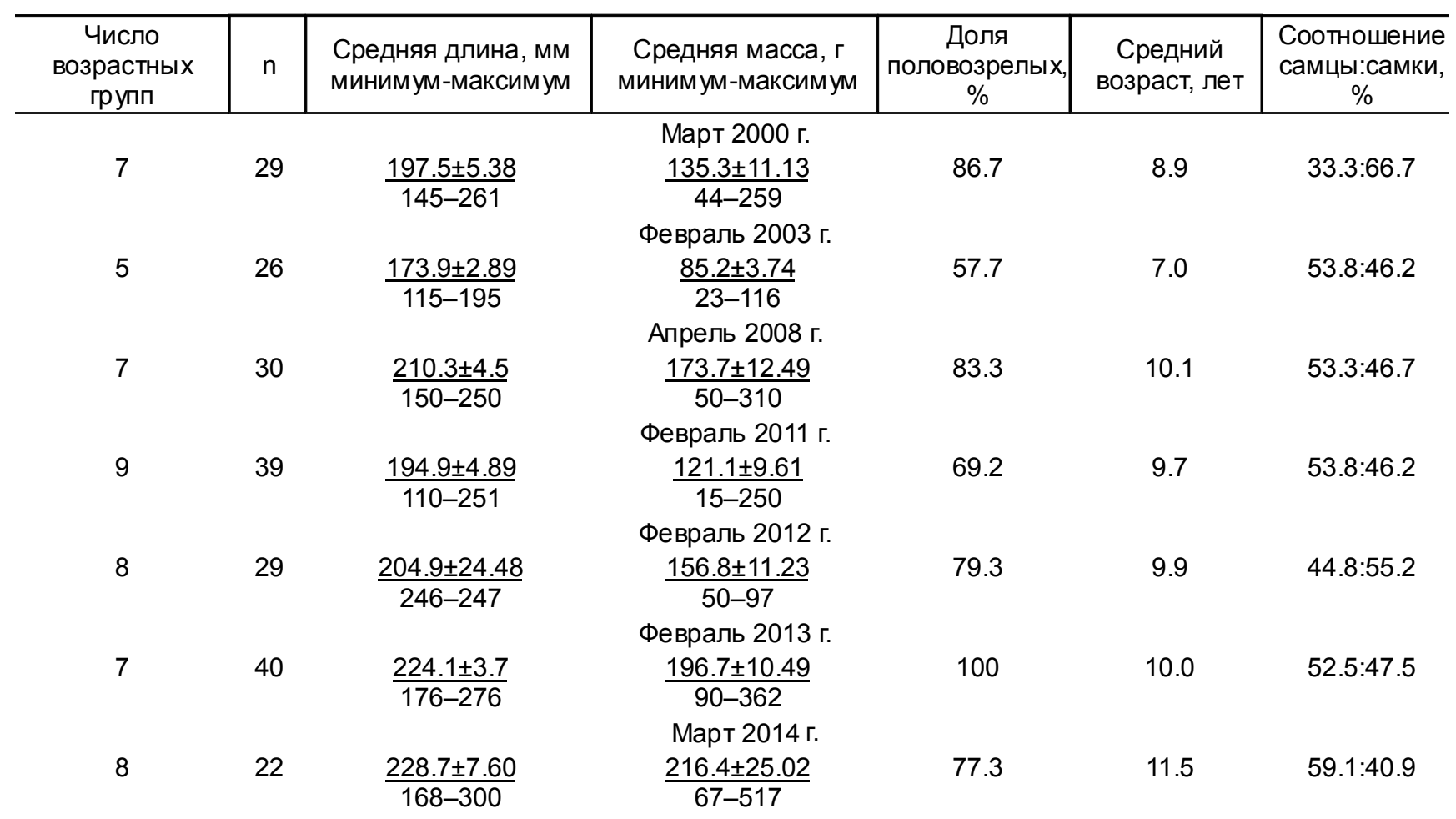

полное соответствие выявленной на охарактеризованных выше озерах тенденции в отношении динамики показателей окуня (табл. 3).

Еще в одном водоеме той же озерно-речной системы бассейна р. Малый Паток, условно обозначенном как озеро 6 , подледные обследования проведены в 2008-2014 гг. (табл. 4). Расположено оно на высоте 224 м над ур.м., площадь 4.2 га. Треугольное по форме и сточное по характеру по отношению к соседнему озеру 7 и, соответственно, к реке Малый Паток, озеро 6 не обладает развитой литоралью. Дно сложено крупными валунами. Глубина: максимальная 18.0 м, преобладающая - 6-7 м. Хорошо развиты макрофиты: осока, нардосмия, хвощи, зеленые мхи, вахта.

Очевидно, что, как и в случае с ранее рассмотренными озерами, наблюдается последовательное увеличение размерно-весовых показателей и среднего возраста окуня. Сокращение в 2013 г. в контрольных уловах числа возрастных групп может быть связано с заметно меньшей величиной выборки в этом году по сравнению с таковой в 2008 и 2014 гг. (сходная картина выявлена при расчете биологических показателей улова окуня в озеpe 11).

Озеро 7 расположено на высоте 219.4 м над ур.м., его площадь 14.4 га. Округлое по форме, при этом сильно изрезанное, обладающее двумя островами, оно является проточным по отношению к озерам 6 и 19 и, в конечном счете, к руслу p. Малый Паток. Практически все берега залесенные. Дно каменистое, на глубине илистое. Наиболее часто встречаются глубины 1.5-2.0 м, максимальная - 10.7 м. Отличается от большинства окружающих озер выраженным зеленоватым оттенком цвета воды. Данные по окуню озера 7 демонстрируют заметную межгодовую вариабельность (табл. 5), однако они полностью соответствуют общей тенденции - в 2014 г. все показатели демонстрируют рост.

Озеро 11 расположено на высоте 230.9 м над ур.м., его площадь 3.3 га. Это вкруговую поросшее лесом или частично ивняком, озеро сразу обращает на себя внимание разнообразием при-

Биологическая характеристика уловов окуня в озере 5 бассейна р. Малый Паток

\begin{tabular}{|c|c|c|c|c|c|c|}
\hline $\begin{array}{c}\text { Число } \\
\text { возрастных } \\
\text { групп } \\
\end{array}$ & $\mathrm{n}$ & $\begin{array}{l}\text { Средняя длина, мм } \\
\text { минимум-максимум }\end{array}$ & $\begin{array}{c}\text { Средняя масса, г } \\
\text { минимум-максимум }\end{array}$ & $\begin{array}{c}\text { Доля } \\
\text { половозрелых, } \\
\% \\
\end{array}$ & $\begin{array}{c}\text { Средний } \\
\text { возраст, лет }\end{array}$ & $\begin{array}{c}\text { Соотношение } \\
\text { самцы:самки, } \\
\%\end{array}$ \\
\hline \multicolumn{7}{|c|}{ Апрель 2008 г. } \\
\hline 7 & 30 & $\frac{198.2 \pm 4.31}{123-233}$ & $\frac{153.8 \pm 9.08}{27-246}$ & 90 & 9.2 & $26.7: 7.3$ \\
\hline & & & Март 2014 г. & & & \\
\hline 7 & 29 & $\frac{228.6 \pm 3.14}{206-262}$ & $\frac{205.7 \pm 9.43}{143-321}$ & 100 & 11.4 & $62.1: 37.9$ \\
\hline
\end{tabular}


Биологическая характеристика уловов окуня в озере 6 бассейна р. Малый Паток

\begin{tabular}{|c|c|c|c|c|c|c|}
\hline $\begin{array}{c}\text { Число } \\
\text { возрастных } \\
\text { групп } \\
\end{array}$ & $\mathrm{n}$ & $\begin{array}{l}\text { Средняя длина, мм } \\
\text { минимум-максимум }\end{array}$ & $\begin{array}{c}\text { Средняя масса, г } \\
\text { минимум-максимум }\end{array}$ & \begin{tabular}{|c|} 
Доля \\
половозрелых, \\
$\%$ \\
\end{tabular} & $\begin{array}{c}\text { Средний } \\
\text { возраст, лет }\end{array}$ & $\begin{array}{c}\text { Соотношение } \\
\text { самцы:самки, } \\
\% \\
\end{array}$ \\
\hline \multicolumn{7}{|c|}{ Апрель 2008 г. } \\
\hline 5 & 30 & $\frac{164.8 \pm 5.41}{140-240}$ & $\frac{66.7 \pm 9.48}{31-225}$ & 40 & 6.9 & $46.7: 53.3$ \\
\hline 2 & 16 & $\frac{170 \pm 1.82}{161-183}$ & $\begin{array}{c}\text { Февраль } 2013 \text { г. } \\
\frac{73.7 \pm 2.60}{90-211}\end{array}$ & 62.5 & 8.4 & 43.8:56.3 \\
\hline 5 & 27 & $\frac{178.6 \pm 2.16}{159-205}$ & $\begin{array}{c}\text { Март } 2014 \text { г. } \\
\frac{94 \pm 3.08}{66-125}\end{array}$ & 81.5 & 7.4 & 25.9:74.1 \\
\hline
\end{tabular}

Биологическая характеристика уловов окуня в озере 7 бассейна р. Малый Паток

\begin{tabular}{|c|c|c|c|c|c|c|}
\hline $\begin{array}{c}\text { Число } \\
\text { возрастных } \\
\text { групп }\end{array}$ & $n$ & $\begin{array}{l}\text { Средняя длина, мм } \\
\text { миним ум-максимум }\end{array}$ & $\begin{array}{c}\text { Средняя масса, г } \\
\text { минимум-максимум }\end{array}$ & $\begin{array}{c}\text { Доля } \\
\text { половозрелых, } \\
\% \\
\end{array}$ & $\begin{array}{c}\text { Средний } \\
\text { возраст, лет }\end{array}$ & $\begin{array}{c}\text { Соотношение } \\
\text { самцы:самки, } \\
\% \\
\end{array}$ \\
\hline \multicolumn{7}{|c|}{ Апрель 2005 г. } \\
\hline 7 & 19 & $\frac{253.6 \pm 11.63}{196-365}$ & $\frac{349.4 \pm 55.9}{124-1003}$ & 77.8 & 10.2 & $50: 50$ \\
\hline 9 & 29 & $\frac{205.3 \pm 9.83}{143-403}$ & $\begin{array}{c}\text { Май } 2007 \text { г. } \\
\frac{192.3 \pm 46.13}{47-1373}\end{array}$ & 44.8 & 9.1 & 48.3:51.7 \\
\hline 11 & 27 & $\frac{159.5 \pm 10.94}{98-318}$ & $\begin{array}{l}\text { Апрель } 2008 \text { г. } \\
\frac{106.5 \pm 28.85}{12-646}\end{array}$ & 25.9 & 6.8 & 51.9:48.1 \\
\hline 12 & 30 & $\frac{216.9 \pm 6.42}{111-366}$ & $\begin{array}{l}\text { Март } 2014 \text { г. } \\
\frac{224.8 \pm 21.3}{21-924}\end{array}$ & 60 & 10.3 & $55: 45$ \\
\hline
\end{tabular}

сущих ему биотопов. Оно напрямую соединяется короткой протокой с рекой и в то же время короткой перемычкой - с одним еще довольно глубоким ледниковым озером. В озеро 11 впадает ручей, имеющий горный характер. Грунты также достаточно разнообразны - от илистых и песчаных до галечниковых и валунных. Преобладают относительно большие (от 2.5 до 8.0 м) глубины, а в центральной части установлена рекордная среди всех обследованных в данном районе озер глубина - 23.0 м.
Как следует из табл. 6, только число возрастных групп окуня из озера 11 за пять-шесть лет после первого подледного обследования сократилось, тогда как остальные показатели либо существенно возросли (размерно-весовые), либо в целом остались на прежнем высоком уровне (средний возраст).

Обладающее поросшими лесом высокими задернованными берегами озеро 12 площадью 5.5 га образует несколько небольших заливов и характеризуется не меньшим, чем озеро 11 , разнооб-

Биологическая характеристика уловов окуня в озере 11 бассейна р. Малый Паток

\begin{tabular}{|c|c|c|c|c|c|c|}
\hline $\begin{array}{c}\text { Число } \\
\text { возрастных } \\
\text { групп }\end{array}$ & $\mathrm{n}$ & $\begin{array}{l}\text { Средняя длина, мм } \\
\text { минимум-максимум }\end{array}$ & $\begin{array}{c}\text { Средняя масса, г } \\
\text { минимум-максимум }\end{array}$ & $\begin{array}{c}\text { Доля } \\
\text { половозрелых, } \\
\% \\
\end{array}$ & $\begin{array}{c}\text { Средний } \\
\text { возраст, лет }\end{array}$ & $\begin{array}{c}\text { Соотношение } \\
\text { самцы:самки, } \\
\%\end{array}$ \\
\hline \multicolumn{7}{|c|}{ Апрель 2008 г. } \\
\hline \multirow[t]{2}{*}{9} & 30 & $\frac{241.9 \pm 7.44}{158-330}$ & $\frac{260.7 \pm 27.56}{56-659}$ & 86.7 & 11.4 & 43.3:56.7 \\
\hline & & & Февраль 2013 г. & & & \\
\hline \multirow[t]{2}{*}{6} & 10 & $\frac{250.4 \pm 9.40}{211-308}$ & $\frac{322 \pm 36.48}{176-532}$ & 100 & 11.4 & $30: 70$ \\
\hline & & & Март 2014 г. & & & \\
\hline 5 & 24 & $\frac{244 \pm 5.94}{200-305}$ & $\frac{285.4 \pm 23}{144-563}$ & 100 & 12.0 & 41.7:58.3 \\
\hline
\end{tabular}


Биологическая характеристика уловов окуня в озере 12 бассейна р. Малый Паток

\begin{tabular}{|c|c|c|c|c|c|c|}
\hline $\begin{array}{c}\text { Число } \\
\text { возрастных } \\
\text { групп } \\
\end{array}$ & $\mathrm{n}$ & $\begin{array}{l}\text { Средняя длина, мм } \\
\text { минимум-максимум }\end{array}$ & $\begin{array}{c}\text { Средняя масса, г } \\
\text { минимум-максимум }\end{array}$ & $\begin{array}{c}\text { Доля } \\
\text { половозрелых, } \\
\% \\
\end{array}$ & $\begin{array}{c}\text { Средний } \\
\text { возраст, лет }\end{array}$ & $\begin{array}{c}\text { Соотношение } \\
\text { самцы:самки, \% }\end{array}$ \\
\hline 7 & 31 & $\frac{176.3 \pm 5.22}{123-222}$ & $\begin{array}{l}\text { Апрель } 2008 \text { г. } \\
\frac{105 \pm 9.47}{29-205}\end{array}$ & 61.3 & 7.7 & $45.2: 54.8$ \\
\hline 7 & 23 & $\frac{207.5 \pm 6.02}{172-272}$ & $\begin{array}{l}\text { Февраль } 2011 \text { г. } \\
\frac{158.1 \pm 17.99}{79-371}\end{array}$ & 82.6 & 9.7 & $26.1: 73.9$ \\
\hline 8 & 19 & $\frac{203.9 \pm 8.68}{104-254}$ & $\begin{array}{l}\text { Март } 2014 \text { г. } \\
\frac{158.7 \pm 15.4}{40-265}\end{array}$ & 78.9 & 10.3 & 57.9:42.1 \\
\hline
\end{tabular}

разием представленных донных грунтов. Оно расположено на высоте 231 м над ур.м. Водоем достаточно глубокий, весьма обычны глубины от 2 до 13 м, максимальная глубина - 17 м.

Биологические показатели окуня из озера 12 за период наблюдений также в целом улучшились, стабилизировавшись на новом уровне в 2011-2014 гг. (табл. 7).

Единственное на ключевом участке замкнутое, не имеющее постоянного соединения с рекой или другими водоемами озеро 13 обследовано пятикратно (табл. 8). Озеро расположено на высоте 231 м над ур.м., его площадь 2 га. Этот водоем, имеющий географические координаты $64^{\circ} 19^{\prime} 50^{\prime \prime}$ с.ш. и $59^{\circ} 07^{\prime} 20^{\prime \prime}$ в.д. и овальную форму, представляет собой достаточно редкий для среднего течения бассейна р. Малый Паток пример озера, не имеющего постоянного соединения с другими водоемами. Подобная связь появляется лишь в годы с наиболее высокими уровнями воды в период весеннего половодья. Берега озера либо высокие и задернованные, либо пологие и заболоченные. Северный и восточный берега поросли лесом, остальные - открытые. Береговая линия простая. Дно илистое или торфянистое. Максимальная глубина -8.7 м, распространенная - 1.32.8 м. Как видно из табл. 8 , в данном случае имеет место общая стабильность величин основных биологических показателей, за исключением лишь числа возрастных групп.

Таким образом, результаты обследования озерных группировок окуня на зимних местообитаниях в ряде озер бассейна р. Малый Паток однозначно свидетельствуют о долговременном улучшении значений популяционных характеристик. Следует отметить, что до организации на западных склонах Северного и Приполярного Урала национального парка «Югыд ва» в озерах бассейна вели промысловый лов рыбы, негативно сказавшийся на состоянии рыбных ресурсов к середине 90-х гг. прошлого столетия.

При обследовании, проведенном в зимний период 2008 г., установлено, что максимальный средний возраст рыб в контрольных уловах окуня отмечен в озере 11 , далее значения этого показателя выстроилась в следующей последовательности (по убыванию): озеро $11>$ озеро $4>$ озеро $5>$ озеро $13>$ озеро $12>$ озеро $6>$ озе-

Биологическая характеристика уловов окуня в озере 13 бассейна р. Малый Паток

Таблица 8

\begin{tabular}{|c|c|c|c|c|c|c|}
\hline $\begin{array}{c}\text { Число } \\
\text { возрастных } \\
\text { групп } \\
\end{array}$ & $\mathrm{n}$ & $\begin{array}{l}\text { Средняя длина, мм } \\
\text { минимум-максимум }\end{array}$ & $\begin{array}{c}\text { Средняя масса, г } \\
\text { минимум-максимум }\end{array}$ & $\begin{array}{c}\text { Доля } \\
\text { половозрелых, } \\
\% \\
\end{array}$ & $\begin{array}{c}\text { Средний } \\
\text { возраст, лет }\end{array}$ & $\begin{array}{c}\text { Соотношение } \\
\text { самцы:самки, \% }\end{array}$ \\
\hline \multicolumn{7}{|c|}{ Апрель 2008 г. } \\
\hline 4 & 25 & $\frac{176 \pm 6.19}{123-212}$ & $\begin{array}{l}\frac{91.3 \pm 9.37}{25-149} \\
\text { Февраль 2011 г. }\end{array}$ & 84 & 7.8 & $60: 40$ \\
\hline 7 & 27 & $\frac{192.1 \pm 5.2}{125-234}$ & $\begin{array}{l}\frac{119 \pm 8.88}{49-207} \\
\text { Февраль } 2012 \text { г. }\end{array}$ & 81.5 & 8.8 & 48.1:51.9 \\
\hline 8 & 8 & $\frac{193.3 \pm 12.68}{151-264}$ & $\begin{array}{l}\frac{124.3 \pm 25.99}{52-276} \\
\text { Февраль } 2013 \text { г. }\end{array}$ & 52.5 & 8.6 & $37.5: 62.5$ \\
\hline 4 & 5 & $\frac{204.4 \pm 8.54}{181-233}$ & $\begin{array}{l}\frac{137.8 \pm 20.46}{90-211} \\
\text { Март } 2014 \text { г. }\end{array}$ & 80 & 8.6 & $20: 80$ \\
\hline 7 & 22 & $\frac{188.9 \pm 5.12}{149-236}$ & $\frac{107.8 \pm 8.89}{53-222}$ & 72.7 & 8.5 & 40.9:59.1 \\
\hline
\end{tabular}


ро $7>$ озеро 2. Несколько иной порядок имела аналогичная последовательность показателя средней массы окуня, за исключением выборок из первых трех водоемов: озеро $11>$ озеро $4>$ озеро $5>$ озеро $7>$ озеро $12>$ озеро $13>$ озеро $6>$ озеро 2. В 2014 г. прослежена сходная градация по величине среднего возраста, длины и массы (рис. 2-4). Это наводит на мысль о наличии более общей закономерности, сводящейся к возможной устойчивости различий среди группировок, обитающих в разных водоемах одной и той же озерно-речной системы.

С этих позиций весьма интересным представляется сопоставление и обобщение накопленных за годы наших исследований ихтиофауны и рыбного населения бассейна p. Малый Паток данных о биологических показателях окуня в период открытой воды (табл. 9). Анализ этой таблицы позволяет констатировать, что самые мелкие размеры у этого вида отмечены в озерах 2,5 и 24 ; в частности, средняя масса окуня этих водоемов и в наших сборах никогда не превышала 100 г. Чуть крупнее оказались окуни из озер 4, 9 и 13 (средняя масса не более 150 г). До 200 г составляет величина этого показателя у рыб из озер 10-12 и 22. Более 300 г в среднем весят особи из озер 17 и 19.

С июня 2004 по июнь 2015 г. зарегистрировано чрезвычайно существенное увеличение средней массы окуня из озера 14 (со 141 до 231 г за год). Еще более впечатляюще возрастание величины параметpa (с 327 до 636 г) с июня 2002 г. до августа 2008 г. у рыб из озера 8. Заметим, что аналогичное увеличение показателя (с 350 до 500 г) имело место в случае с окунем озера 7 , однако в последующие годы большинство характеристик, за исключением числа обнаруженных возрастных групп, заметно уступало таковым из целого ряда озер системы. Это особенно обращает на себя внимание при анализе результатов, полученных в 2008 г.

Параллельно с характеристикой ряда биологических показателей окуня выполнено изучение состава его подледного питания. В пищевой спектр окуня озера 2 входят две группы кормовых объектов и растительные остатки. Более $80 \%$ массы пищевого комка солый Паток. Паток. Паток. ставляют личинки поденок, 10 \% приходится на долю личинок хирономид и еще чуть более 7 \% на растительные остатки.

Несколько разнообразнее оказалось питание особей из озера 4. Если по численности доминировали личинки хирономид, почти в четыре раза превосходя в этом отношении личинок поденок и почти в 20 раз - двукрылых, то по массе их вклад оказался вполне сопоставим (хирономиды почти $35 \%$, поденки - немногим меньше 30 \%). Следует отметить, что, как и в озере 2 , для окуня из озера 4 характерна еще большая доля растительных остатков в формировании пищевого комка (более $13 \%$ ).

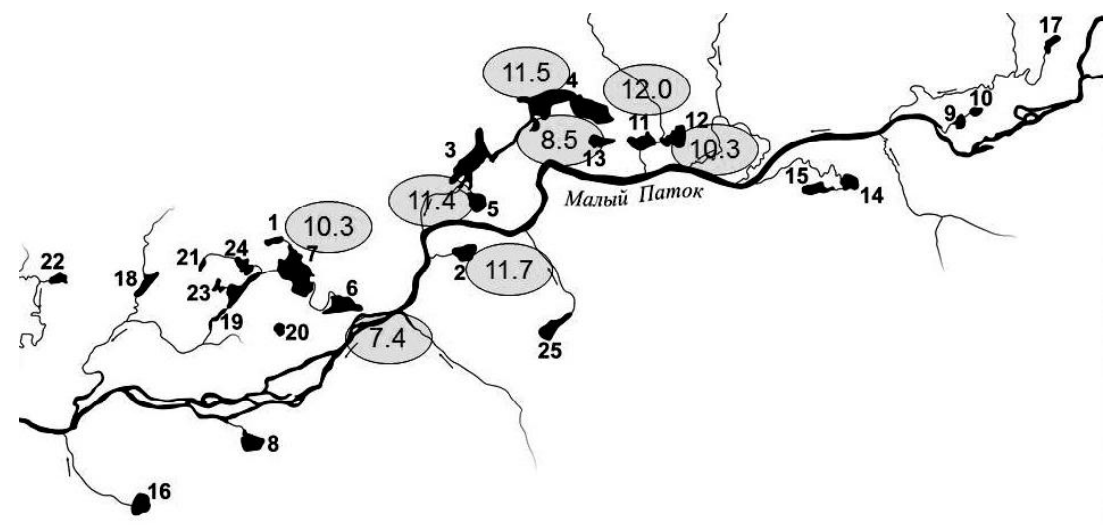

Рис. 2. Средний возраст уловов окуня (годы) в озерах бассейна р. Ма-

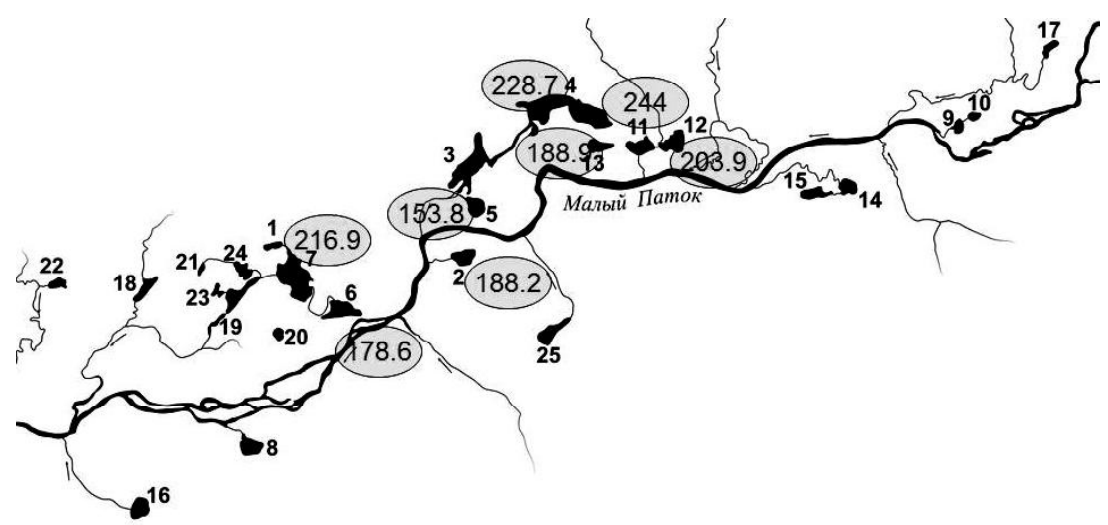

Рис. 3. Средняя длина уловов окуня (мм) в озерах бассейна р. Малый

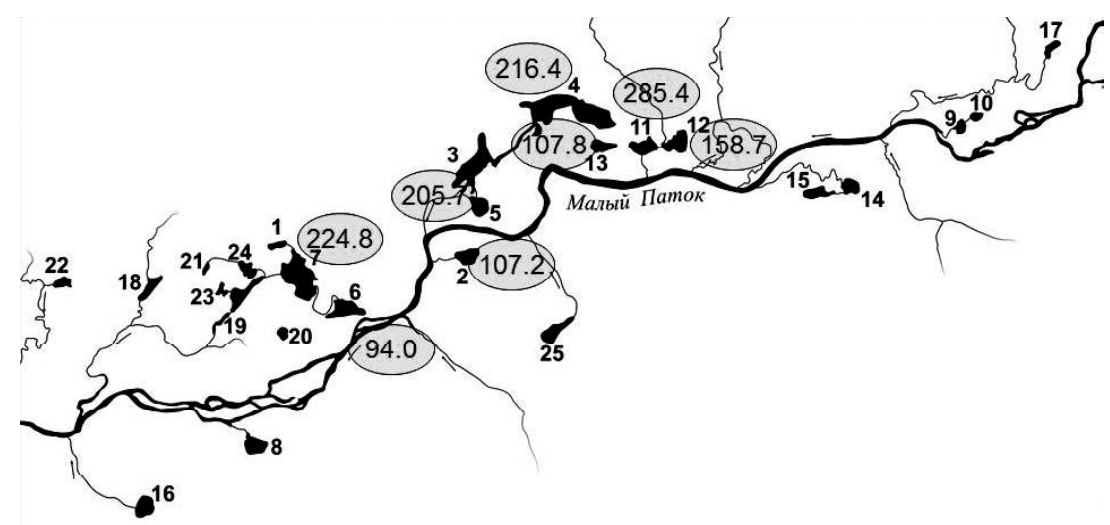

Рис. 4. Средняя масса уловов окуня (г) в озерах бассейна р. Малый 
Биологическая характеристика уловов окуня в некоторых озерах бассейна р. Малый Паток

\begin{tabular}{|c|c|c|c|c|c|}
\hline $\begin{array}{c}\text { Число } \\
\text { возрастных } \\
\text { групп } \\
\end{array}$ & $\begin{array}{l}\text { Средняя длина, мм } \\
\text { минимум-максимум }\end{array}$ & $\begin{array}{c}\text { Средняя масса, г } \\
\text { минимум-максимум }\end{array}$ & $\begin{array}{c}\text { Доля } \\
\text { половозрелых, \% }\end{array}$ & $\begin{array}{c}\text { Средний } \\
\text { возраст, лет }\end{array}$ & $\begin{array}{l}\text { Соотношение } \\
\text { самцы:самки, \% }\end{array}$ \\
\hline \multicolumn{6}{|c|}{ Озеро 2. Июнь 2001 г. } \\
\hline- & $\frac{153.6 \pm 4.39}{95-232}$ & $\frac{80 \pm 6.08}{14-243}$ & 57.1 & - & $48.6: 51.4$ \\
\hline \multicolumn{6}{|c|}{ Озеро 2. Август 2002 г. } \\
\hline 3 & $\frac{124.1 \pm 9.32}{67-268.5}$ & $\frac{48.3 \pm 13.85}{4.5-317.8}$ & 8.8 & 3.4 & $23.5: 76.5$ \\
\hline \multicolumn{6}{|c|}{ Озеро 2. Июнь 2004 г. } \\
\hline 3 & $\frac{138.9 \pm 2.52}{130-153}$ & $\frac{41.4 \pm 2.55}{32-60}$ & 41.7 & 3.9 & $58.3: 41.7$ \\
\hline \multicolumn{6}{|c|}{ Озеро 2. Июнь 2005 г. } \\
\hline 9 & $\frac{154.9 \pm 3.35}{105-302}$ & $\frac{63.5 \pm 7.24}{17-483}$ & 67.1 & 5.4 & $72.2: 27.8$ \\
\hline \multicolumn{6}{|c|}{ Озеро 5. Июнь 2005 г. } \\
\hline 3 & $\frac{611.8 \pm 38.55}{500-665}$ & $\frac{84.8 \pm 4.82}{55-153}$ & 88.9 & 6.1 & 88.9:11.1 \\
\hline \multicolumn{6}{|c|}{ Озеро 7. Июнь 2001 г. } \\
\hline- & $\frac{213.8 \pm 6.85}{160-323}$ & $\frac{198.1 \pm 24.68}{67-684}$ & 100 & - & $15.4: 84.6$ \\
\hline \multicolumn{6}{|c|}{ Озеро 7. Май 2005 г. } \\
\hline 8 & $\frac{205.3 \pm 9.83}{143-403}$ & $\frac{192.3 \pm 46.13}{47-1373}$ & 44.8 & 9.1 & 48.3:51.7 \\
\hline \multicolumn{6}{|c|}{ Озеро 7. Июнь 2005 г. } \\
\hline 6 & $\frac{284.6 \pm 19.39}{171-365}$ & $\frac{497 \pm 88.55}{77-908}$ & 83.3 & 11.4 & 33.3:66.7 \\
\hline \multicolumn{6}{|c|}{ Озеро 8. Июнь 2002 г. } \\
\hline 14 & $\frac{248.9 \pm 7.12}{130-372}$ & $\frac{326.6 \pm 24.52}{34-941}$ & 79.3 & 9.9 & $36.8: 63.2$ \\
\hline \multicolumn{6}{|c|}{ Озеро 8. Август 2008 г. } \\
\hline 9 & $\frac{314.8 \pm 5.89}{225-386}$ & $\frac{635.3 \pm 32.79}{205-1176}$ & 90.2 & 12.3 & $27.5: 72.5$ \\
\hline \multicolumn{6}{|c|}{ Озеро 9. Июнь 2002 г. } \\
\hline 5 & $\frac{128.3 \pm 15.87}{70-268}$ & $\frac{58.9 \pm 28}{5-358}$ & 33.3 & 3.9 & $58.3: 41.7$ \\
\hline \multicolumn{6}{|c|}{ Озеро 9. Июнь 2004 г. } \\
\hline 9 & $\frac{172.4 \pm 5.26}{123-335}$ & $\frac{111.7 \pm 15.62}{15.62}$ & 59.3 & 6.1 & 46.3:53.7 \\
\hline \multicolumn{6}{|c|}{ Озеро 10. Июнь 2002 г. } \\
\hline 7 & $\frac{192.9 \pm 22.02}{72-135}$ & $\frac{215.1 \pm 48.58}{5-742}$ & 60 & 7.4 & $50: 50$ \\
\hline \multicolumn{6}{|c|}{ Озеро 10. Июнь 2004 г. } \\
\hline 9 & $\frac{198.2 \pm 8.10}{124-138}$ & $\frac{205.3 \pm 30.96}{30-818}$ & 58.3 & 7.5 & $35.4: 64.6$ \\
\hline \multicolumn{6}{|c|}{ Озеро 11. Июнь 2002 г. } \\
\hline 2 & $\frac{231.8 \pm 3.64}{225-242}$ & $\frac{205 \pm 14-83}{171-243}$ & 100 & 8.3 & $50: 50$ \\
\hline \multicolumn{6}{|c|}{ Озеро 12. Июнь 2002 г. } \\
\hline 5 & $\frac{236.8 \pm 5.9}{220-260}$ & $\frac{212 \pm 14.05}{172-272}$ & 100 & 9.0 & 33.3:66.7 \\
\hline \multicolumn{6}{|c|}{ Озеро 13. Июнь 2002 г. } \\
\hline 3 & $\begin{array}{c}188.8 \pm 5.77 \\
160-224\end{array}$ & $\begin{array}{c}102.5 \pm 11.25 \\
58-200\end{array}$ & 76.9 & 7.0 & $46.2: 53.8$ \\
\hline \multicolumn{6}{|c|}{ Озеро 13. Июнь 2004 г. } \\
\hline 2 & $\begin{array}{c}193.9 \pm 3.01 \\
176-215\end{array}$ & $\begin{array}{c}109.6 \pm 5.93 \\
80-157\end{array}$ & 81.8 & 6.9 & $45.5: 54.5$ \\
\hline \multicolumn{6}{|c|}{ Озеро 13. Июнь 2005 г. } \\
\hline 2 & $\begin{array}{c}144 \pm 26.59 \\
77-191\end{array}$ & $\begin{array}{l}61.4 \pm 21.89 \\
8-101\end{array}$ & 40 & 5.0 & $60: 40$ \\
\hline
\end{tabular}


Окончание табл. 9

\begin{tabular}{|c|c|c|c|c|c|}
\hline $\begin{array}{c}\text { Число } \\
\text { возрастных } \\
\text { групп }\end{array}$ & $\begin{array}{l}\text { Средняя длина, мм } \\
\text { минимум-максимум }\end{array}$ & $\begin{array}{c}\text { Средняя масса, г } \\
\text { минимум-максимум }\end{array}$ & $\begin{array}{c}\text { Доля } \\
\text { половозрелых, \% }\end{array}$ & $\begin{array}{c}\text { Средний } \\
\text { возраст, лет }\end{array}$ & $\begin{array}{c}\text { Соотношение } \\
\text { самцы:самки, \% }\end{array}$ \\
\hline \multicolumn{6}{|c|}{ Озеро 14. Июнь 2004 г. } \\
\hline 6 & $\frac{196.3 \pm 7.04}{133-254}$ & $\frac{141.3 \pm 16.55}{36-299}$ & 95.0 & 7.2 & $85: 15$ \\
\hline \multicolumn{6}{|c|}{ Озеро 14. Июнь 2005 г. } \\
\hline 3 & $\frac{277.7 \pm 6.49}{253-310}$ & $\frac{230.5 \pm 20.23}{144-334}$ & 54.5 & 5.6 & $9.1: 90.0$ \\
\hline \multicolumn{6}{|c|}{ Озеро 17. Июнь 2004 г. } \\
\hline & $172-372$ & $\frac{94-1254}{94}$ & & & \\
\hline \multicolumn{6}{|c|}{ Озеро 19. Июнь 2004 г. } \\
\hline 7 & $\frac{244.7 \pm 12.51}{118-352}$ & $\frac{309.9 \pm 45.22}{30-860}$ & 76.9 & 9.5 & $38.5: 61.5$ \\
\hline \multicolumn{6}{|c|}{ Озеро 22. Июнь 2005 г. } \\
\hline 12 & $\frac{195.0 \pm 5.78}{64-341}$ & $\frac{218.5 \pm 18.06}{4-789}$ & 40.4 & 7.2 & $49.5: 50.5$ \\
\hline \multicolumn{6}{|c|}{ Озеро 24. Июнь 2005 г. } \\
\hline 5 & $\frac{128.9 \pm 11.97}{65-206}$ & $\frac{57 \pm 13.08}{4-174}$ & 38.9 & 4.1 & 66.7:33.3 \\
\hline
\end{tabular}

Еще один пищевой компонент - личинки ручейников - появились в питании окуня из озера 5. Его навеска в пищевом комке невелика (чуть менее $3 \%$ ), но при этом она заметно превосходит долю личинок хирономид, оказавшуюся совершенно ничтожной. Доминировали личинки поденок, которые составили почти 70 \% содержимого пищеварительного тракта при полном отсутствии растительной пищи.

Так же, как и в питании окуня из озера 5 , в озере 4 рыбы практически не питались личинками хирономид: только у одной из особей обнаружено 2 экз. этих личинок. Львиную долю содержимого желудочно-кишечного тракта составили личинки поденок и растительные остатки. Еще $6 \%$ массы пищевого комка осталось за двукрылыми.

Окунь из озера 7 практически не питался, что может рассматриваться как дополнительный аргумент при обсуждении обнаруженного нами в 2008 г. феномена ухудшения размерно-возрастных показателей контрольных уловов окуня.

При изучении питания окуня из озера 11 установлено, что его основу составляют личинки поденок и ручейников и растительные остатки, а также в существенно меньшей степени личинки хирономид.

Пищевой спектр окуня из озера 12 коренным образом отличается от такового в большинстве изученных озер. Здесь половину массы пищевого комка составили личинки хирономид, а доля личинок ручейников и двукрылых оказалась крайне низкой.

Напротив, как и в преобладающем числе случаев, в питании у окуня из озера 13 преобладали личинки поденок, заметно превосходя долю личинок хирономид, при полном отсутствии растительных остатков.
Заключение
Таким образом, впервые проведено исследование распределения окуня в подледный период в озерах бассейна р. Малый Паток. Установлено, что его зимние местообитания существенно отличаются от летних. Как правило, это связано с полным промерзанием зимой мелководных озер и миграцией окуня на этот период в другие водоемы единой озерно-речной системы.

Несмотря на наличие постоянной или временной, как в случае с озером 13 , связи озер с основным руслом реки и между собой, населяющие различные озера группировки окуня отличаются между собой по ряду биологических показателей. Максимальными размерно-возрастными параметрами характеризуется выборка окуня из озера 11 , а диаметрально противоположными - из озеpa 2.

Размерно-возрастные характеристики окуня несколько не в полной мере коррелировали с числом возрастных групп в уловах и долей половозрелых особей. Действительно, в отношении первого показателя в 2008 г. последовательность озер с позиции его убывания выглядела следующим образом: озеро $7>$ озеро $11>$ озера 4,5 и $12>$ озеро $2>$ озеро $6>$ озеро 13 . Окунь озера 7 , занимающий здесь лидирующую позицию, неожиданно сдает ее при сопоставлении доли половозрелых рыб в уловах и оказывается замыкающим последовательность контрольных уловов в сравниваемых озерах: озеро $5>$ озеро $11>$ озеро $13>$ озеро $4>$ озеро $2>$ озеро $12>$ озеро $6>$ озеро 7.

Попытки каким-то образом объяснить эти отличия не сводятся к предположениям о существовании в перечне возможных причин этого явления межсезонных миграций в пределах озерно- 
речной системы даже таких оседлых видов рыб, как окунь, возможными различиями темпа роста и полового созревания окуня в различных озерах, ошибками «случайных» контрольных выборок окуня и т.п. По всей видимости, все это сказывается на параметрах уловов окуня, однако дальнейшие исследования могут выявить и другие, пока неизвестные факторы, которые могут существенно (или даже лимитирующе) влиять на величину и межгодовую динамику используемых стандартных биологических показателей рыб.

Обнаружены черты сходства и различия в характере зимнего питания окуня. Это может быть обусловлено не только имеющей естественный характер спецификой кормовой базы озер, различных по величине, строению, характеру дна, питанию, водной растительности (Бассейн ..., 2007), но и имеющими адаптивный характер локальными особенностями пищевого поведения окуня из тех или иных озер (Михеев, 2006).

Обобщая полученные данные, можно утверждать, что ключевое значение для сохранения разнообразия группировок окуня имеет целостность и сохранность озерно-речной системы бассейна p. Малый Паток как функциональной иерархии взаимосвязанных и взаимообусловленных разнотипных водоемов единой экосистемы с исторически сложившимися связями и экотонами.

Необходимо особо отметить, что огромную роль в поддержании на высоком уровне естественного разнообразия рыбного населения бассейна р. Малый Паток (Бассейн ..., 2007; Пономарев, 2019) и близкого к естественному состоянию популяций обитающих здесь рыб, в частности, окуня, сыграло включение водосбора в территорию национального парка «Югыд ва», а также социально-экологическое партнерство этого природоохранного учреждения с ООО «Газпром трансгаз Ухта» и Институтом биологии Коми НЦ УрО PAH.

Работа выполнена в рамках государственного задания по теле "Распространение, систелатика и пространственная организация фауны и населения животных таежных и тундровых ландшафтов и экосистем европейского северо-востока России» № Гр . 0414-2018-0005.

\section{ЛИТЕРАТУРА}

Бассейн реки Малый Паток: дикая природа. - Сыктывкар, 2007. - 216 с.

Методическое пособие по изучению питания и пищевых отношений рыб в естественных условиях. Москва : Наука, 1974. - 254 с.

Мина, М. В. Рост животных // М. В. Мина, Г. А. Клевезаль. - Москва : Наука, 1976. - 292 с.

Михеев, В. Н. Неоднородность среды и трофические отношения у рыб / В. Н. Михеев. - Москва : Наука, 2006. - 191 с.

Никольский, Г. В. Экология рыб / Г. В. Никольский. - Москва : Высшая школа, 1974. - 436 с.

Пономарев, В. И. Фауна водоемов бассейна р. Малый Паток (Приполярный Урал). 1. Рыбы / В. И. Пономарев // Биология внутренних вод. - 2019. Вып. 4. - C. 14-24. - doi: 10.1134/S0320965219040302

Пономарев, В. И. Биотопическое распределение хариуса реки Щугор в подледный период / В. И. Пономарев, О. А. Лоскутова, Е. Ю. Серегина // Экологофаунистические исследования на европейском северовостоке России. - Сыктывкар, 1998. - С. 82-89. - (Труды Коми НЦ УрО РАН ; № 157).

Правдин, И. Ф. Руководство по изучению рыб (преимущественно пресноводных) / И. Ф. Правдин. - Москва : Пищевая промышленность, 1966. - 376 с.

\title{
WINTER DISTRIBUTION OF PERCH IN A MOUNTAIN RIVER-LAKE SYSTEM
}

\author{
V.I. Ponomarev \\ Institute of Biology of Komi Scientific Centre of the Ural Branch of the Russian Academy of Sciences, Syktyvkar
}

\begin{abstract}
Summary. This paper is dedicated to the research on ice-cover periods distribution of perch, one of the most dominant fish species in lakes belonging to the Pechora River basin. Field studies were carried out in NovemberApril 2000-2014 in the Maly Patok River basin (the western slopes of the Pre-Polar Urals). Perch was observed in 8 out of 19 lakes inhabited by the species in ice-free periods. A general description of the distribution and the state of perch aggregations in their winter habitats in mountain and piedmont lakes belonging to the Maly Patok River basin (the Pre-Polar Urals) in the area where the river leaves the mountains and enters the valley was made. It was established that winter habitats of perch differ considerably from its summer habitats. As a rule, this is connected with the complete freezing of shallow lakes in winter periods and perch migrations to other water bodies of the integrated river-lake system. Differences in perch age-length indices in different water bodies of the river-lake system were identified. There are also similarities and differences in perch winter feeding habits. This may be caused both by natural features of forage reserve specifics of the lakes which differ in size, structure, bottom nature, nourishment, aquatic vegetation and by local peculiarities of the perch feeding behavior in different lakes, which are characterized by the adaptive nature. The results of the comparative study of a number of biological parameters indicate the stability and long-term improvement of the state of the perch population.
\end{abstract}

Key words: perch, the Pre-Polar Urals, mountain and piedmont lakes, spatial distribution, biological parameters 